\title{
Attitudes and behaviors of undergraduate students toward environmental issues
}

\author{
${ }^{1}{ }^{*}$ H. Müderrisoğlu; ${ }^{2}$ A. Altanlar \\ ${ }^{1}$ Faculty of Forestry, Departmant of Landscape Architecture, Duzce University, 81100 Beciyorukler Koyu, \\ Düzce, Turkey \\ ${ }^{2}$ Faculty of Architecture, University of Amasya, Turkey \\ Received 19 February 2010; revised 26 September 2010; accepted 17 November 2010; available online 1 December 2010
}

\begin{abstract}
The studies carried out throughout the world have indicated that there are differences between environmental attitudes and environmentally responsible behaviors of undergraduate students. In what ways the environmental attitudes and behaviors of the students who will protect and manage the resources of the country in the future have changed is an important issue? This study was aimed at determining the environmental attitudes and environmentally responsible behaviors of the undergraduate students of Abant Ýzzet Baysal University toward environmental issues. In addition, the effects of the faculty in which the students are enrolled, locality and gender on the determined environmental attitudes and environmentally responsible behaviors of the students were investigated. The data were gathered from 507 students in 2005. To explain the environmental attitudes and environmentally responsible behaviors of undergraduate students toward environmental issues, factor analysis was used with Varimax Rotation method. To determine the changes of the environmental attitudes and environmentally responsible behaviors of the students with regard to the faculty, locality and gender, one-way analysis of variance was used. According to the results, students highly support the environmental attitudes and highly participate only in consumerism behaviors. Finally, it was determined if faculty and gender had an effect on the environmental attitudes and behaviors of the students.
\end{abstract}

Key words: Ecological Paradigm Scale; Environmental Responsibility; Gender; University

\section{INTRODUCTION}

The increasing environmental activities toward the end of the 1960s reached the peak with "Earth Day" in 1970 (Thapa, 1999). Since then, there have been changes in the behaviors and attitudes of people toward environmental issues. However, while a majority of people have adopted environmental attitudes, environmentally responsible behaviors have not been reflected in life in the same level (Tarant and Cordel, 1977; Nouri et al.,2008; Chen, 2010; Chen et al.,2010). In the 1980s, a different viewpoint was brought up by scientists. According to this new viewpoint, how the environmental problems are perceived by society and how the society reacts to these problems have become important (Huang and Shih; 2009). In those years, the most commonly used scale to measure the environmental awareness was New Environmental Paradigm (NEP) scale which was brought up by Dunlap

$\triangle$ *Corresponding Author Email: haldunm@duzce.edu.tr Tel.: +90 536964 4696; Fax: +90 3805421136 and Van Lierre (1978). NEP scale has been widely used in literature in the last two decades. This scale has been used among the general society and the farmers (Albercht et al., 1982), ethnic groups (Caron, 1989) and students (Bechtel et al., 1999; Shobeiri et al., 2006).

Students have always played an active role in the activities leading to the development of environmental awareness. Therefore, several studies have been carried out to understand the environmental attitudes and behaviors of the students. In addition, the facts that the students will be the ones who will manage and consume the future resources have been effective in doing studies related to the students. It is possible to infer two different results from these studies. First, although the environmental attitudes of the students are very developed, their behaviors are affected by the economic concerns (Thompson and Gasteiger, 1985; Gigliotti, 1992; Imandoust and Gadam 2007; Chien and Shih, 2007). 
Second, developed environmental awareness of the students reflect their behaviors in the same level (Shetzer et al., 1991).

The studies aiming to determine the criteria causing these different environmental attitudes and behaviors are gathered in two main parts, namely, those examining socio-demographic factors and those examining the belief, psychological structures of societies (Dietz et $a l ., 1998)$. The studies examining the effects of sociodemographic characteristics on environmental attitudes and behaviors investigated age (Mohai and Twight, 1987), gender (Mohai, 1992; Sasidharan and Thapa, 1999; Shobeiri et al., 2007), ethnicity (Caro and Ewert, 1995), locality (Sasidharan and Thapa, 1999), education (Thapa, 1999). Jones and Dunlap (1992), Steel (1996) examined the effects of psychology on environmental attitudes and behaviors while Stern et al. (1995), Dunlap et al. (2000) examined the effects of the beliefs and values of the society on environmental attitudes and behaviors. The studies carried out in the past indicated that environmental attitude and awareness changed depending on gender. In most of the studies, it was determined that the attitudes and behaviors of the women toward environmental protection were more developed than men (Davidson and Freudberg, 1996; Burger et al., 1998). However, Arcury et al. (1987) stated in their studies that information and concerns about environmental problems were more developed among men than women. Cary (1993) stated that attitudes and behaviors concerning the problem changed depending on the distance of the residents from environmental problems. In addition, Robertson and Burdge (1998) stated that the people living in the urban areas are more concerned with environmental issues than those living in the rural areas. Tehrani et al. 2009 and 2010; Thapa (1999) observed some changes in the environmental attitudes and behaviors of the students due to their education. He found out that the students who had education on environment were more aware of environmental attitudes than the other students.

In Turkey, studies about environmental awareness have started in the 2000s. University students were mostly the subject of these studies. Talay et al. (2003) who studied the environmental awareness of students in Ankara University found that the department the students attend in school has been effective on their environmental awareness. Budak et al. (2005), did a similar study where students at the Faculty of Agriculture served as the sample group. The effects of students' characteristics on their environmental awareness were examined. It was found that students from rural areas, girls, and younger students have more sophisticated environmental awareness than those from urban areas, boys and older ones, respectively. Vaizoglu et al. (2005) proved that students with medicine degree do not have enough environmental awareness. The environmental awareness studies done in Turkey are very limited and there is no study about environmental behaviors.

The studies carried out in other parts of the world indicated that there are differences between the environmental attitudes and environmentally responsible behaviors of undergraduate students. The aim of this study is to determine how some of the sociodemographic characteristics affect environmental attitudes and behaviors of undergraduate students. Thus, the differences between the environmental attitudes and behaviors of the students will be explained. This study aims to find the answers to these three questions:

- Are there any differences between the environmental attitudes and behaviors of undergraduate students studying in different faculties?

- Is there a difference in environmental attitudes and behaviors to gender?

- Is there a difference in environmental attitudes and behaviors to locality?

The data for this study were collected in 2005 from the undergraduate students in the cities of Bolu and Duzce in the Western Black Sea Region of Turkey.

\section{MATERIALS AND METHODS}

Study Area

According to the data taken from the census done in 2000, approximately $50 \%$ of the Turkish populations are younger than 24 years old. There is a central student selection exam in Turkey for the university. Therefore, students in the universities come from different cities and social groups. As a result of these diverse data expected from the universities and with reference to this expectation, the study area was selected. This study was carried out in Abant Ýzzet Baysal University, Konuralp Campus in Düzce and Gölköy in Bolu. In these two campuses, there are two Schools (School of Physical Education and Sports, School of Nursing), and six faculties (Faculty of Medicine, Faculty of Technical Education, Faculty of 
Table 1: Profile of participant

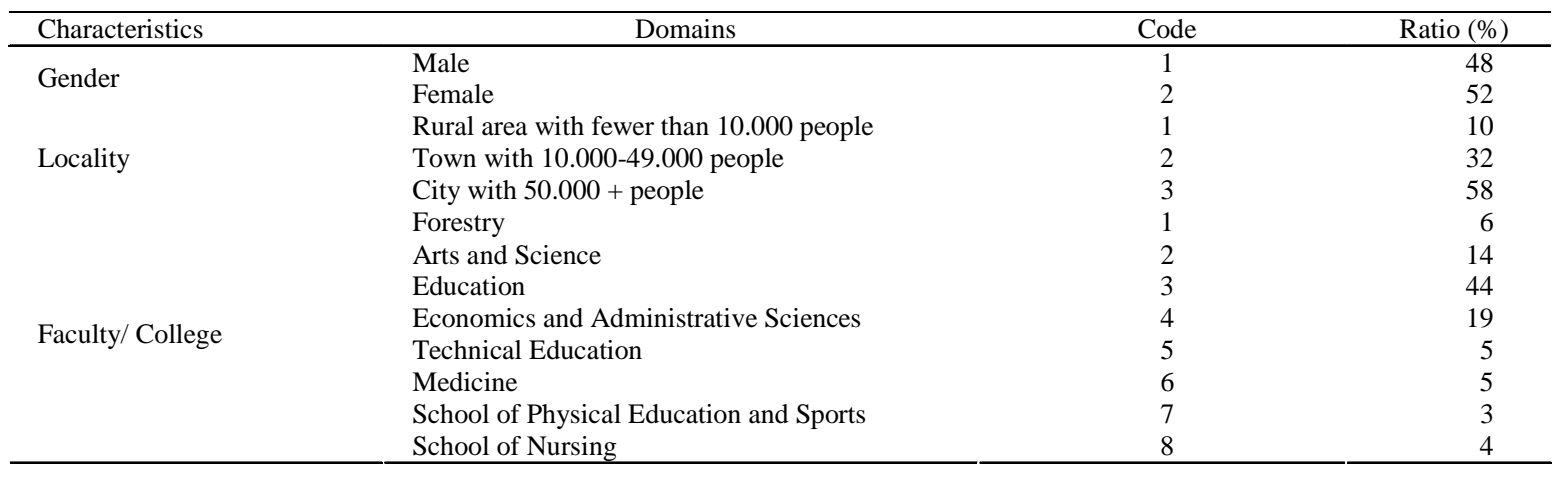

Table 2: Frequency distributions (\%) for faculty/college students’ environmental attitudes

\begin{tabular}{|c|c|c|c|c|c|c|}
\hline Questionnaire statement* & SA & MA & $\mathrm{U}$ & MD & $\mathrm{SD}$ & $\begin{array}{l}\text { \# of } \\
\text { cases }\end{array}$ \\
\hline $\begin{array}{l}\text { 1If things continue on their present course will soon experience a major ecological } \\
\text { catastrophe }\end{array}$ & 58 & 33 & 6 & 2 & 1 & 503 \\
\hline 2The earth is like a spaceship with very limited room and resources & 37 & 36 & 16 & 9 & 2 & 488 \\
\hline 3Humans are severely abusing the environment & 54 & 38 & 4 & 3 & 1 & 501 \\
\hline 4The balance of nature is very delicate and easily upset & 40 & 39 & 10 & 9 & 2 & 489 \\
\hline 5We are approaching the limit of the number of people that the earth can support & 22 & 35 & 31 & 9 & 3 & 494 \\
\hline 6When humans interfere with nature, if often produces disastrous consequences & 36 & 37 & 17 & 8 & 2 & 500 \\
\hline $\begin{array}{l}\text { 7The balance of nature is strong enough to cope with the impacts of modern industrial } \\
\text { nations }\end{array}$ & 6 & 14 & 25 & 39 & 16 & 494 \\
\hline 8The earth has plenty of natural resources if we just learn how to develop them & 41 & 40 & 11 & 5 & 3 & 490 \\
\hline 9Human ingenuity will insure that we do not make the earth unlivable & 18 & 26 & 29 & 19 & 8 & 497 \\
\hline 10 Humans will eventually learn enough about how nature works to be able to control it & 16 & 32 & 31 & 15 & 6 & 496 \\
\hline 11The so-called ecological crisis facing humankind has been greatly exaggerated & 4 & 12 & 29 & 41 & 14 & 485 \\
\hline 12Humans have the right to modify the natural environment to suit their needs & 6 & 12 & 14 & 33 & 35 & 494 \\
\hline 13Plants and animals have as much right as humans to exist & 71 & 20 & 4 & 2 & 3 & 499 \\
\hline 14Humans were meant to rule over the rest of nature & 14 & 31 & 27 & 21 & 7 & 494 \\
\hline 15Despite our special abilities humans are still subject to the laws of nature & 33 & 41 & 17 & 6 & 3 & 500 \\
\hline
\end{tabular}

* Ceded on a 5 pt. Likert type scale where: SA (1)= Strongly agree, MA (2)= Moderately agree, U (3)= Undecided, MD (4)= Moderately disagree,

SD (5)=Strongly disagree

Forestry, Faculty of Education, Faculty of Arts and Science, Faculty of Economics). The total number of students was 13150 .

\section{Sample size}

Sample size was calculated over 8350 people in the third and fourth class although there were 13150 students in the study area. The reason for this is that the vocational classes become harder after the second class. In the table of sample size, the level of reliability for the minimum number of people was taken as $95 \%$ (1996), and the accepted sampling error level was taken as $99 \%$ $(0,1)$ (Orhunbilge, 1997). According to this reliability table, 507 questionnaires were made using the face to face method and all the questionnaires were used in this study.

\section{Determining environmental attitudes}

The New Ecological Paradigm Scale (NEP) developed was used in determining the environmental attitudes. The scale consisted of 15 items grouped in 5 main ecological attitudes in 5-point Likert type format, which ranged from 1 (strongly agree) to 5 (strongly disagree). The concepts of 5 main titles are as follows (Table 2):
a. reality of limits to growth (3 items)
b. anti-anthropocentrism (3 items)
c. fragility of nature's balance (3 items)
d. rejection of exemptionalism (3 items) 
Table 3: Factor loading for university student's environmental attitudes

\begin{tabular}{|c|c|c|c|}
\hline Questionnaire statement* & $\begin{array}{l}\text { Ecocentric } \\
\text { Attitude }\end{array}$ & $\begin{array}{l}\text { Technocentric } \\
\text { Attitude }\end{array}$ & $\begin{array}{l}\text { Dualcentric } \\
\text { Attitude }\end{array}$ \\
\hline $\begin{array}{l}\text { If things continue on their present course will soon experience a major ecological } \\
\text { catastrophe }\end{array}$ & 0,50 & - & - \\
\hline The earth is like a spaceship with very limited room and resources & 0,55 & - & - \\
\hline Humans are severely abusing the environment & 0,61 & - & - \\
\hline The balance of nature is very delicate and easily upset & 0,74 & - & - \\
\hline Human ingenuity will insure that we do not make the earth unlivable & 0,60 & - & - \\
\hline $\begin{array}{l}\text { The balance of nature is strong enough to cope with the impacts of modern industrial } \\
\text { nations }\end{array}$ & - & 0,63 & - \\
\hline The so-called ecological crisis facing humankind has been greatly exaggerated & - & 0,64 & - \\
\hline Humans have the right to modify the natural environment to suit their needs & - & 0,66 & - \\
\hline Plants and animals have as much right as humans to exist & - & - & 0,61 \\
\hline Despite our special abilities humans are still subject to the laws of nature & - & - & 0,63 \\
\hline Mean & 2,02 & 3,37 & 2,00 \\
\hline \% Variance & 19 & 13 & 12 \\
\hline Alpha value & 0,74 & 0,55 & 0,50 \\
\hline
\end{tabular}

* Ceded on a 5 pt. Likert type scale where: SA (1)= Strongly agree, MA (2)= Moderately agree, U (3)= Undecided, MD (4)= Moderately disagree, SD (5)=Strongly disagree

Table 4: Frequency distributions (\%) for faculty/college students' environmentally responsible behaviors

\begin{tabular}{|c|c|c|c|c|c|c|}
\hline Questionnaire statement* & $\mathrm{U}$ & $\mathrm{F}$ & $\mathrm{S}$ & $\mathrm{O}$ & $\mathrm{R}$ & $\begin{array}{l}\text { \# of } \\
\text { cases }\end{array}$ \\
\hline \multicolumn{7}{|l|}{ HOW OFTEN HAVE YOU.......... } \\
\hline 1. Used biodegradable, no phosphate soaps ore detergents & 24 & 26 & 29 & 15 & 6 & 491 \\
\hline 2. Read labels on products to see if the contents were environmental safe & 11 & 23 & 40 & 19 & 7 & 504 \\
\hline 3. Avoided buying products in aerosol containers & 12 & 26 & 34 & 20 & 8 & 499 \\
\hline 4. Purchased a product because it was packaged in reusable or recyclable containers & 5 & 18 & 30 & 26 & 21 & 499 \\
\hline 5. Switched from one brand to another due to concern for the environment & 10 & 17 & 33 & 26 & 14 & 499 \\
\hline 6. Stopped buying from a company which showed a disregard for the environment & 27 & 26 & 24 & 15 & 8 & 495 \\
\hline 7. Avoided restaurants that put take-out food in Styrofoam containers & 15 & 28 & 25 & 17 & 15 & 500 \\
\hline 8. Bought products made from recycled material & 5 & 22 & 41 & 23 & 6 & 493 \\
\hline 9. Cut down on the use of your car by using public transportation, car pooling, etc & 46 & 18 & 10 & 10 & 16 & 482 \\
\hline $\begin{array}{l}\text { 10. Written to your elected officials expressing your opinions on environmental } \\
\text { problems }\end{array}$ & 1 & 5 & 16 & 26 & 52 & 499 \\
\hline 11. Investigated your elected officials' voting record on environmental issues & 6 & 13 & 28 & 31 & 22 & 487 \\
\hline 12. Used legal measures to stop events you though would damage the environment & 3 & 11 & 24 & 29 & 33 & 499 \\
\hline 13. Reported environmental crimes to the proper authorities & 7 & 12 & 27 & 30 & 24 & 496 \\
\hline 14. Voted for a politician due to his/her record on protection the environment & 8 & 11 & 20 & 13 & 48 & 490 \\
\hline 15. Donated money or paid membership dues to a conservation organization & 3 & 5 & 16 & 24 & 52 & 488 \\
\hline 16. Joined in community cleanup efforts & 3 & 8 & 26 & 31 & 32 & 493 \\
\hline 17. Watched TV programs about environmental problems & 11 & 28 & 36 & 20 & 5 & 502 \\
\hline 18. Talked to others about environmental issues & 8 & 28 & 39 & 22 & 3 & 502 \\
\hline 19. Read publication that focus on environmental issues & 7 & 25 & 41 & 22 & 5 & 501 \\
\hline 20. Tried to learn what you can do to help solve environmental issues & 2 & 11 & 31 & 36 & 20 & 497 \\
\hline $\begin{array}{l}\text { 21. Enrolled in a course for the sole purpose of learning more about environmental } \\
\text { issues }\end{array}$ & 2 & 7 & 21 & 31 & 39 & 499 \\
\hline 22. Recycled glass bottles or jars or aluminum cans & 10 & 17 & 30 & 22 & 21 & 500 \\
\hline 23. Recycled old newspaper & 16 & 22 & 23 & 22 & 17 & 502 \\
\hline 24. Sorted your trash to separate non-recyclable from recyclable material & 9 & 14 & 22 & 21 & 34 & 504 \\
\hline
\end{tabular}

* Ceded on a 5 pt. Likert type scale where: U (1)=Usually, F (2)= Frequently, S (3)= Sometimes, O (4)= Occasionally, R (5)= Rarely 
e. possibility of eco-crisis or ecological catastrophe (3 items) (Sasidharan and Thapa, 1999).

\section{Determination of participants' characteristics}

The students were asked their gender (male, female), residence (rural area with fewer than 10.000 people, town with 10.000-49.000 people, city with 50.000 + people) and their faculties and schools (Faculty of Forestry, Faculty of Arts and Science, Faculty of Education, Faculty of Economics and Administrative Sciences, Faculty of Technical Education, Faculty of Medicine, School of Physical Education and Sports, School of Nursing) in order to determine the characteristics of the participants in the study. The responses obtained were tabulated in Table 1.

\section{RESULTS AND DISCUSSION}

Profile of participants

Of the 507 students participating in the study carried out in A.I.B.U Konuralp Campus in Düzce and Gölköy in Bolu , 48 \% were male and $52 \%$ female; $10 \%$ live in rural areas, $32 \%$ in towns, $58 \%$ in the cities; $44 \%$ attend the Faculty of Education, $19 \%$ the Faculty of Economics and Administrative sciences, $14 \%$ the Faculty of Arts and Science, $6 \%$ the Faculty of Forestry, $5 \%$ the Faculty of Technical Education, $5 \%$ the Faculty of Medicine, $4 \%$ the School of Nursing, and $3 \%$ the School of Physical Education and Sports. Large majority of respondents are single. These faculties and schools were coded according to their course densities on environment. The students taking the most number of courses on environment were the students of the Faculty of Forestry.

\section{Environmental attitudes}

The 15 items within the scale were initially subjected to basic frequency summary analysis. As shown in Table 2, participants support the environmental attitudes. However, this support is not high for each item. Environmental attitudes supported in the range of 81-92\% are as follows: humans are severely abusing the environment, plants and animals have as much right as humans to exist, if things continue their present course we will soon experience a major ecological catastrophe, and we need to learn how to develop natural sources on earth. Environmental attitudes in the range of $73-79 \%$ are as follows: the balance of nature is easily upset, humans were meant to rule over the rest of the nature, humans are subjected to the laws of nature and when humans interfere with nature, it often produces disastrous consequences. Environmental attitudes supported in the range of 44$57 \%$ are as follows: human ingenuity will insure that we do not make the earth unlivable, humans were meant to rule over nature and they will eventually learn enough about how nature works to be able to control, the earth is like a spaceship with very limited room and resources. There are also environmental attitudes that are not supported in the range of 45-68 \%; these are humans have the right to modify the natural environment to suit their needs, the balance of nature is strong enough to cope with the impacts of modern industrial solutions and the so-called ecological crisis facing humankind has been greatly exaggerated. In order to explain the environmental attitudes of the students that participated in the study, factor analysis was used with Varimax Rotation method. As seen in Table 3, three factors are found that explained the environmental attitudes with a variance of $44 \%$. In naming these factors, Thapa (1999) is used. 1. Factor is explained with a variance of $19 \%$ and Cronbach's alpha is 0,74 . The alpha value computed indicates that this factor is quite reliable (Özdamar, 1999). 1. Factor is named as ecocentric as the items within this factor generally substantiate the claim that the environment is in a precarious position, and the impact of humans can be detrimental to the survival of humankind. 2. Factor is explained with a variance of $13 \%$ and Cronbach's alpha is 0,55 . The computed alpha value indicates that factor has a low reliability. 2. Factor is named as technocentric. The items included in this factor show that technology can be used in the environmental solutions and coping with the problems. 3 . Factor is explained with a variance of $12 \%$ and Cronbach's alpha is 0,50 . The computed alpha value indicates that the factor has a low reliability. 3. Factor is named as dualcentric. The items included in this factor state that there is a symbiotic relationship between humans and the other living things. Of these three factors determined, the most supported ones are dualcentric attitudes. It is followed by ecocentric attitudes. Technocentric attitudes are not supported by the students who participated in the questionnaire.

\section{Environmentally responsible behaviors}

Frequency distributions for the 24 items of the ERBI were also examined and the results are illustrated in Table 4. The students answering the questionnaire highly participated in the environmentally responsible 
behaviors (ERB), in the range of 9-64\%. The environmentally responsible behavior that the students highly participated at $64 \%$ is their preference for mass means of transportation. The reason for this is the economic situation of students in Turkey who cannot afford to buy a car. The environmentally responsible behaviors of 50-53 \% of students are as follows: they do not shop from companies that damage nature and they do not use soap and detergent that damage nature. The environmentally responsible behavior of $47 \%$ of students is avoiding places that put take-out food in styrofoam containers. Environmentally responsible behaviors of 32-39 \% of students are watching TV programs on environmental issues, avoiding detrimental gases to environment, trying to recycle papers and newspapers, talking about environmental problems, reading things written on the label of the product and publications that focus on environmental issues. Environmentally responsible behaviors with 23$27 \%$ participation are purchasing products produced from recycled materials, changing the brand harmful to environment with an environment friendly brand, trying to recycle glass bottles and jars, separating trash as recyclable or non-recyclable, purchasing a product because it was packaged in reusable or recyclable containers. The participation ratios of the students to the rest of the environmentally responsible behaviors are very low. The things rarely done are writing articles about environmental problems, paying money for environmental protection associations and participating in the seminars or courses about environment. In order to explain the environmentally responsible behaviors of students that participated in the study, factor analysis was used with Varimax Rotation method. As seen in Table 5, three factors are found that explained the environmentally responsible behaviors with a variance of $40 \%$. 1 . Factor is explained with a variance of $18 \%$ and Cronbach's alpha is 0,77 . The alpha value computed indicates that this factor is quite reliable. 1. Factor is named as activism. The items within this factor indicate the attempt of the students to get information and become active in protecting. 2. Factor is explained with a variance of $13 \%$ and Cronbach's alpha is 0,69 . The computed alpha value indicates that factor is quite reliable. 2 . Factor is named as consumerism. The items included in this factor show different purchasing behaviors. 3. Factor is explained with a variance of $9 \%$ and Cronbach's alpha is 0,79 . The computed alpha value indicates that factor is quite reliable. 3 . Factor is named as recycling. The items included in this factor state the attempt for recycling. The students stated that they highly participated in consumerism behaviors followed by recycling behaviors. The least participation is found for the activism behaviors.

\section{The effect of the faculty on environmental attitudes and behaviors}

To find the response to the first question of the study, it was examined whether these three environmental attitudes (ecocentric, technocentric, dualcentric) and three environmentally responsible behaviors (activism, consumerism, recycling) differ with regard to the faculties the students attended. Oneway analysis of variance was used for this. As seen in Table 6, environmental attitudes of students do not undergo a statistically important change according to the faculties they attend. In addition, two important relationships are found between environmentally responsible behaviors of the students and the university they attend (Table 6). Statistically, the most important relationship is between activism and faculties. Accordingly, the students attending SPES, FTE, and FEAS, respectively, are inclined to participate in activism behaviors. The students having the least possibility to participate in the activism behaviors are the ones attending SN, FE, FF. the second important relationship is between recycling behavior and faculties. This indicates that the students attending FTE, FEAS and FAS are more inclined to participate in recycling behaviors. The students having the least possibility to participate in recycling behaviors are the ones attending FF, SPES, and SN.

\section{The effect of locality on environmental attitudes and behaviors}

To find the answer to the second question of the study, it was examined if three environmental attitudes (ecocentric, technocentric, dualcentric) and three environmentally responsible behaviors (activism, consumerism, recycling) differ with regard to the localities of the students. For this, one-way analysis of variance was used. As shown in Table 7, locality has no statistical effect on environmental attitudes and behaviors.

\section{The effect of gender on environmental attitudes and behaviors}

On the last question of the study, one-way analysis of variance was used in order to indicate if 
Int. J. Emviron. Sci. Tech., 8 (1), 159-168, Winter 2011

Table 5: Factor loading for university student's environmentally responsible behaviors

\begin{tabular}{|c|c|c|c|}
\hline Questionnaire statement* & $\begin{array}{l}\text { Activism } \\
\text { Behavior }\end{array}$ & $\begin{array}{c}\text { Consumerism } \\
\text { Behavior }\end{array}$ & $\begin{array}{l}\text { Recycling } \\
\text { Behavior }\end{array}$ \\
\hline 21. Enrolled in a course for the sole purpose of learning more about environmental issues & 0,69 & - & - \\
\hline 18. Talked to others about environmental issues & 0,69 & - & - \\
\hline 20. Tried to learn what you can do to help solve environmental issues & 0,69 & - & - \\
\hline 19. Read publication that focus on environmental issues & 0,63 & - & - \\
\hline 13. Reported environmental crimes to the proper authorities & 0,63 & - & - \\
\hline 16. Joined in community cleanup efforts & 0,62 & - & - \\
\hline 11. Investigated your elected officials’ voting record on environmental issues & 0,58 & - & - \\
\hline 17. Watched TV programs about environmental problems & 0,53 & - & - \\
\hline 10. Written to your elected officials expressing your opinions on environmental problems & 0,50 & - & - \\
\hline 15. Donated money or paid membership dues to a conservation organization & 0,46 & - & - \\
\hline 12. Used legal measures to stop events you though would damage the environment & 0,37 & - & - \\
\hline 14. Voted for a politician due to his/her record on protection the environment & 0,35 & - & - \\
\hline 5. Switched from one brand to another due to concern for the environment & - & 0,66 & - \\
\hline 6. Stopped buying from a company which showed a disregard for the environment & - & 0,59 & - \\
\hline 8. Bought products made from recycled material & - & 0,59 & - \\
\hline 4. Purchased a product because it was packaged in reusable or recyclable containers & - & 0,58 & - \\
\hline 2. Read labels on products to see if the contents were environmental safe & - & 0,56 & - \\
\hline 3. Avoided buying products in aerosol containers & - & 0,55 & - \\
\hline 7. Avoided restaurants that put take-out food in Styrofoam containers & - & 0,53 & - \\
\hline 1. Used biodegradable, no phosphate soaps ore detergents & - & 0,39 & - \\
\hline 9. Cut down on the use of your car by using public transportation, car pooling, etc & - & 0,30 & - \\
\hline 22. Recycled glass bottles or jars or aluminum cans & - & - & 0,75 \\
\hline 24. Sorted your trash to separate non-recyclable from recyclable material & - & - & 0,72 \\
\hline 23. Recycled old newspaper & - & - & 0,68 \\
\hline Mean & 3,61 & 2,85 & 3,28 \\
\hline \% Variance & 18 & 13 & 9 \\
\hline Alpha value & 0,77 & 0,69 & 0,79 \\
\hline
\end{tabular}

* Ceded on a 5 pt. Likert type scale where: U (1)=Usually, F (2)= Frequently, S (3)= Sometimes, O (4)= Occasionally, R (5)= Rarely

Table 6: Comparison of environmental attitudes and behaviors by faculty

\begin{tabular}{|c|c|c|c|c|c|c|c|c|c|c|c|}
\hline & & $\begin{array}{l}\mathrm{FF}^{\mathrm{a}} \\
\text { Mean }\end{array}$ & $\begin{array}{l}\text { FAS }^{b} \\
\text { Mean }\end{array}$ & $\begin{array}{l}\mathrm{FE}^{\mathrm{C}} \\
\text { Mean }\end{array}$ & $\begin{array}{l}\text { FEAS }^{\mathrm{d}} \\
\text { Mean }\end{array}$ & $\begin{array}{l}\text { FTE }^{e} \\
\text { Mean }\end{array}$ & $\begin{array}{l}\mathrm{FM}^{\mathrm{f}} \\
\text { Mean }\end{array}$ & $\begin{array}{l}\text { SPES }^{g} \\
\text { Mean }\end{array}$ & $\begin{array}{l}\mathrm{SN}^{\mathrm{h}} \\
\text { Mean }\end{array}$ & $\begin{array}{l}\text { Total } \\
\text { Mean }\end{array}$ & F value \\
\hline \multirow{3}{*}{ Attitudes } & Ecocentric & 2,13 & 2,00 & 2,03 & 1,94 & 2,19 & 1,89 & 1,82 & 2,16 & 2,02 & $1,08 \mathrm{~ns}$ \\
\hline & Technocentric & 3,56 & 3,44 & 3,38 & 3,25 & 3,15 & 3,59 & 3,17 & 3,37 & 3,37 & 1,49 ns \\
\hline & Dualcentric & 1,84 & 2,01 & 2,04 & 1,99 & 2,00 & 1,75 & 1,78 & 2,22 & 2,00 & 1,49 ns \\
\hline \multirow{3}{*}{ Behaviors } & Activism & 3,63 & 3,61 & 3,73 & 3,58 & 3,13 & 3,60 & 2,98 & 3,75 & 3,61 & $3,45 * * *$ \\
\hline & Consumerism & 2,88 & 2,80 & 2,93 & 2,76 & 2,65 & 2,96 & 2,69 & 2,92 & 2,85 & $1,25 \mathrm{~ns}$ \\
\hline & Recycling & 3,63 & 3,04 & 3,41 & 3,04 & 2,98 & 3,18 & 3,61 & 3,48 & 3,28 & $2,57 *$ \\
\hline
\end{tabular}

* pd”0,05, ${ }^{* * *}$ pd”0,001, ns non-significant

${ }^{a}$ Faculty of Forestry, ${ }^{b}$ Faculty of Arts and Science, ${ }^{c}$ Faculty of Education, ${ }^{d}$ Faculty of Economics and Administrative Sciences,

${ }^{\text {e }}$ Faculty of Technical Education, ${ }^{\mathrm{f}}$ Faculty of Medicine, ${ }^{\mathrm{g}}$ School of Physical Education and Sports, ${ }^{\text {h }}$ School of Nursing

environmental attitudes and behaviors showed any change with regard to gender. As seen in Table 8, there are three important relationships between environmental attitudes and gender. Statistically, the most important relationship is between ecocentric attitudes and gender. This indicates that female students are more inclined to ecocentric attitudes than male students. Based on the second statistically important relationship, male students are more inclined to technocentric attitudes than female students. Finally, female students are more inclined to dualcentric attitudes than male students. In addition, two important relationships are found between environmentally responsible behaviors and gender. The statistically most important relationship is that male students participate more in consumerism behaviors than female 
Environmental attitudes and behaviors

Table 7: Comparison of environmental attitudes and behaviors by locality

\begin{tabular}{|c|c|c|c|c|c|c|}
\hline & & $\begin{array}{c}\text { Rural area } \\
\text { Mean }\end{array}$ & $\begin{array}{l}\text { Town } \\
\text { Mean }\end{array}$ & $\begin{array}{c}\text { City } \\
\text { Mean }\end{array}$ & $\begin{array}{l}\text { Total } \\
\text { Mean }\end{array}$ & F value \\
\hline \multirow{3}{*}{ Attitudes } & Ecocentric & 2,03 & 2,01 & 2,00 & 2,01 & $0,05 \mathrm{~ns}$ \\
\hline & Technocentric & 3,28 & 3,43 & 3,35 & 3,37 & $1,00 \mathrm{~ns}$ \\
\hline & Dualcentric & 2,11 & 1,99 & 1,97 & 1,99 & $1,06 \mathrm{~ns}$ \\
\hline \multirow{3}{*}{ Behaviors } & Activism & 3,63 & 3,57 & 3,63 & 3,61 & $0,24 \mathrm{~ns}$ \\
\hline & Consumerism & 2,75 & 2,87 & 2,85 & 2,85 & $0,49 \mathrm{~ns}$ \\
\hline & Recycling & 3,16 & 3,38 & 3,22 & 3,27 & $1,25 \mathrm{~ns}$ \\
\hline
\end{tabular}

Table 8: Comparison of environmental attitudes and behaviors by gender

\begin{tabular}{|c|c|c|c|c|c|}
\hline & & $\begin{array}{l}\text { Male } \\
\text { Mean }\end{array}$ & $\begin{array}{c}\text { Female } \\
\text { Mean }\end{array}$ & $\begin{array}{l}\text { Total } \\
\text { Mean }\end{array}$ & F value \\
\hline \multirow{3}{*}{ Attitudes } & Ecocentric & 2,11 & 1,93 & 2,02 & $10,43 * * *$ \\
\hline & Technocentric & 3,27 & 3,46 & 3,37 & $7,69 * *$ \\
\hline & Dualcentric & 2,08 & 1,92 & 2,00 & $7,08 * *$ \\
\hline \multirow{3}{*}{ Behaviors } & Activism & 3,64 & 3,59 & 3,61 & $0,49 \mathrm{NS}$ \\
\hline & Consumerism & 2,95 & 2,77 & 2,85 & $8,26 * *$ \\
\hline & Recycling & 3,38 & 3,18 & 3,28 & $4,45^{*}$ \\
\hline
\end{tabular}

* pd"0,05, ${ }^{* *}$ pd"0,01, ${ }^{* * *}$ pd"0,001; NS = Non Significant

students. The second important relationship indicates that female students participate more in recycling behaviors than male students.

\section{CONCLUSION}

This study was aimed at determining the participation of Abant Izzet Baysal University students' environmental attitudes and behaviors and the effects of students' faculties, localities and genders on these.

In this study which supported the previous studies, it has been observed that students highly support the environmental attitudes (Thompson and Gasteiger, 1985; Gigliotti, 1992). This support is higher than those participating in the Thapa's (1999) study. On the other hand, contrary to the study of Shetzer et al. (1991), developed environmental attitudes of the students do not reflect their environmentally responsible behaviors in the same level. Talay et al. (2003) observed the students' environmentally responsible behaviors and found that they join recycling (68\%), and consumerism (46\%) on a high level. Thompson and Gasteiger (1985); Gigliotti (1992) stated that the students are affected by economic concerns with regard to their environmentally responsible behaviors. This result is not supported in the study. In the course of time students have changed their shopping habits. It would not be right to match this with increasing income level because there has not been a distinct change in the income level since the previous study. The causes of this change could be the development of technology, the decreasing prices of the products that are compatible with nature, and the commercials of these products on the national television channels (Subarmadi et al., 2001). According to the results obtained, A. I. B. U students highly participate only in consumerism behaviors.

This study searches the answers for three questions. The first is whether or not the faculty which the students attend is effective on their environmental attitudes and behaviors. Thapa (1999) stated that when the students take more environmental courses, the participation in their environmental attitudes and behaviors increases. In this study, it has been observed that the courses that students take do not affect their environmental attitudes and behaviors. Moreover, the students of Faculty of Forestry, which has the highest number of environmental courses, have less participation in environmentally responsible behaviors when compared to the students of other faculties. This is highly surprising. Positive progress has been observed in environmental behaviors and attitudes of students taking environment classes and living in big cities of Turkey like Ankara and Konya (Talay et al., 2003; Önder ,2006). To find out the reason for different results, Furman (1998) would be helpful. Furman 1998 stated that people are more sensitive to environmental problems in their own living areas than those in other areas. A. I. B. University has two campuses: one is in 
the city of Bolu and another is in the city of Duzce. Both cities are surrounded with beautiful nature and have few environmental problems. This may be the reason for the opposite result of this study compared to former studies about less participation in environmentally responsible behaviors of students who take more environment related classes.

Robertson and Burdge (1998) indicated that people living in the metropolis have developed less environmental awareness than the ones living in the rural parts. The example of A.I.B. University students` does not support the results of Robertson and Burdge (1998). The answer to the second question of the study is that the locality of the students does not affect their environmental attitudes and behaviors. The reason as pointed out above is that the place they live in has more effect on the students' environmental behaviors and attitudes than the places they come from. In this study, it was determined whether or not gender has an effect on environmental attitudes and behaviors. In most of the studies carried out previously, it was stated that women's attitudes and behaviors toward protecting the environment are more developed than men (Davidson and Freudberg, 1996; Burger et al., 1998). The results obtained in this study indicated that gender has a high effect on environmental attitudes and behaviors. Male students' attitudes and behaviors are particularly low. In the study of Thapa (1999), the environmentally responsible behavior that students mostly participate in was recycling. This was evident in the success of the local administration in collecting recycling products. Since the local administrations of the Provinces Düzce and Bolu, which were examples in the study, did not show any attempts in collecting recycling materials and did not have any recycling policies determined by the law throughout the country, participation in recycling behaviors decreased. Considering that this study's examples were students who will protect or manage the resources of the country in the future, it was very important for the participation ratio in activism behaviors to be high. However, this ratio was found to be very low. Therefore, this study concludes with the question "how can lack of participation in activism behaviors be solved?” Does the lack of this kind of responsible behavior exist because university students see environmentalism as a fashion or is it because they are being ignorant? These questions should be discussed in future studies.

\section{REFERENCES}

Albrecht, D.; Bultena, G.; Hoiberg, E.; Nowak, P., (1982). Measuring environmental concern: The new environmental paradigm scale. J. Environ. Educ., 13 (3), 39-43 (5 pages).

Arcury, T. A.; Scollary, S. J.; Johnson, T. P., (1987). Sex diffirences in environmental concern and knowledge: The case of acid rain. Sex Roles., 16, 463-472 (10 pages).

Bechtel, R.; Corral-Verdugo, V.; Pineiro, J., (1999). Environmental belief systems: United States, Brazil and Mexico. J. Cross Cult. Psychol., 30 (1), 122-123 (2 pages).

Budak, B. D.; Budak, F.; Zaimoglu, Z.; Kekeç, S.; Sucu, Y. M., (2005). Behaviour and attitudes of students towards environmental issues of Faculty of Agriculture, Turkey. J. App. Sci., 5 (7), 1224-1227 (4 pages).

Burger, J.; Sanchez, J. W.; Gochfeld, M., (1998). Gender differences in recreational use, environmental attitudes, and perceptions of future land use at the Savannah River site. Environ. Behav., 30, 472-486 (7 pages).

Caro, V.; Ewert, A., (1995). The infulunce of acculturation on enviromental concerns: An exploratory study. J. Environ. Educ., 26, 13-21 (8 pages).

Caron, J. A., (1989). Environmental perspectives of blacks: Acceptance of the "New environmental paradigm". J. Environ. Educ., 20 (3), 21-26 (6 pages).

Cary, J., (1993). The nature of symbolic belief and environmental behavior in a rural setting. Environ. Behav., 25, 555-576 (22 pages).

Chen, C. C., (2010). Spatial inequality in municipal solid waste disposal across regions in developing countries. Int. J. Environ. Sci. Tech. 7 (3), 447-456 (10 pages).

Chen, H. W.; R. F. Yu R. F.; Liaw S. L.; Huang W. C., (2010). Information policy and management framework for environmental protection organization with ecosystem conception. Int. J. Environ. Sci. Tech. 7 (2), 313-326 (14 pages).

Chien, M. K.; Shih L. H., (2007). An empirical study of the implementation of green supply chain management practices in the electrical and electronic industry and their relation to organizational performances. Int. J. Environ. Sci. Tech. 4 (3), 383-394 (12 pages).

Davidson, D. J.; Freudenburg, W. R., (1996). Gender and Environmental risk concerns. Environ. Behav., 28, 302-339 (38 pages).

Dietz, T.; Stern, P. C.; Guagnano, G. A., (1998). Social stuctural and social psychological bases of environmental concern. Environ. Behav., 30, 450-471 (22 pages).

Dunlap, R. E.; Van Liere, K. D., (1978). The New environmental paradigm. J. Environ. Educ., 9 (4), 10-19 (10 pages).

Dunlap, R. E.; Van Liere, K. D.; Mertig, A. G.; Jones, R. E., (2000). Measuring endorsement of the new ecological paradigm: A revised NEP scale. J. Soc. Issues, 56, 425-442 (18 pages).

Furman, A., (1998). A note on environmental concern in a developing country: Results From an Istanbul. Environ. Behav., 30, 520-534 (15 pages).

Gigliotti, L. M., (1992). Environmental attitudes 20 Years of change?. J. Environ. Educ., 24 (1), 15-26 (12 pages).

Huang, P.; Shih, L., (2009). Effective environmental management through environmental knowledge management. Int. J. Environ. Sci. Tech., 6 (1), 35-50 (16 pages).

Imandoust, S. B.; Gadam, S. N., (2007). Are people willing to pay for river water quality, contingent valuation. Int. J. Environ. Sci. Tech., 4 (3), 401-408 (8 pages). 
Jones, R. E.; Dunlap, R. E., (1992). The social bases of environmental concern. Rural Sociology., 57, 57-71 (15 pages).

Mohai, P., (1992). Men, Women and the Environment: An examination of gender gap in environmental concern and activism. Soc. Natur. Resour., 5, 1-19 (20 pages).

Mohai, P.; Twight, B. W., (1987). Age and environmentalism: An elaboration of the Buttel model using national survey evidence. Soc. Sci., 68, 798-815 (18 pages).

Nouri, J.; Karbassi, A. R.; Mirkia, S., (2008). Environmental management of coastal regions in the Caspian Sea. Int. J. Environ. Sci. Tech., 5 (1), 43-52 (10 pages).

Önder, S., (2006). A survey of awareness and behaviour in regard to environmental issues among Seluk University students in Konya, Turkey. J. Appl. Sci., 6 (2), 347-352 (6 pages).

Orhunbilge, N., (1997). Örnekleme yöntemleri ve hipotez testleri, ýstanbul Üniversitesi ýpletme fakültesi, Yayýn., 270, 81-82 (2 pages).

Özdamar, K., (1999). Paket Programlar ile ýstatiksel Veriler Analizi. Kaan Kitapevi, Eskipehir. Cilt., 1, 535 (1 page).

Robertson, R. A.; Burdge, R. J., (1998). Size of place of residence and encounters with the adverse consequences of and support for commerical/ industrial development. Proceedings, 1998 Northeastern Recreation Research Symposium, GTR-NE-255. Randor PA: USDA Forest Service, Northeastern forest experiment station., 81-85 (6 pages).

Sasidharan, V.; Thapa, B., (1999). An exploration of the influence of gender and locality on environmental attitudes, using the new ecological paradigm (NEP) scale. Proceeding of the 1999 Northeastern Recreation Research Symposium. April 11-14, 1999 Bolton Landing, New York. The Pennsylvania State University, 57-61 (5 pages).

Shetzer, L.; Stackman, R. W.; Moore, L. F., (1991). Businessenvironment attitudes and the new environmental paradigm. J. Environ. Educ., 22 (4), 14-21 (8 pages).

Shobeiri, S. M.; Omidvar, B.; Prahallada, N. N., (2006). Influence of gender and type of school on environmental attitude of teachers in Iran and India. Int. J. Environ. Sci. Tech., 3 (4), 351-358 (8 pages).

Shobeiri, S. M.; Omidvar, B.; Prahallada, N. N., (2007). A comperative study of environmental awareness among secondary school students in Iran and India. Int. J. Environ. Res., 1 (1), 28-34 (7 pages).
Smith-Sebasto, N. J., (1995). The effects of environmental studies course on selected variables related to environmentally responsible behavior. J. Environ. Educ., 26 (4), 30-34 (5 pages).

Steel, B., (1996). Thinking globally and acting locally? Environmental attitudes, behavior and activism. J. Environ. Manage., 47, 27-36 (10 pages).

Stern, P.; Dietz, T.; Guagnano, G. A., (1995). The new ecological paradigm in social-psychological context. Environ. Behav., 27, 723-743 (21 pages).

Subarmadi, S.; Suzuki, S.; Kawada, T.; Netti, H.; Soemanti, S.; Tritugasawati, A., (2001). A survey of perception, knowledge, awareness and attitude in regard to environmental problems in a sample of two different social groups in Jakarta, Indonesia. Environ. Dev. Sustain., 3, 169-183 (15 pages).

Talay, I.; Gunduz, S.; Akpinar, N., (2003). On the status of environmental education and awareness of undergraduate students at Ankara University, Turkey. Int. J. Environ. Pollut., 21 (3), 293-308 (16 pages).

Tarrant, M. A.; Cordell, H. K., (1997). The effect of respondent characteristics on general environmental attitude-behavior correspondence. Environ. Behav., 29, 618-637 (20 pages).

Thapa, B., (1999). Environmentalism: A study of undergraduate students. Proceedings of the 1999 northeastern recreation research symposium. April 11-14, 1999 Bolton Landing, New York. The Pennsylvania State University, 41-50 (12 pages).

Tehrani, S. M.; Karbassi, A. R.; Ghoddosi J.; Monavvari, S. M. and Mirbagheri, S. A., (2009). Prediction of energy consumption and urban air pollution reduction in e-shopping adoption. J. Food. Agric. Environ., 7 (3-4), 898-903 (6 pages).

Tehrani, S. M.; Karbassi, A. R.; Monavari, S. M.; Mirbagheri, S. A., (2010). Role of e-shopping management strategy in urban environment. Int. J. Environ. Res., 4 (4), 681-690 (10 pages).

Thompson, J. C.; Gasteiger, E. L., (1985). Environmental attitude survey of university students : 1971 vs. 1981. J. Environ. Educ., 17 (1), 13-22 (10 pages).

Vaizoglu, S.; Altintas, H.; Temel F., (2005). Evaluation of the environmental consciousness of the students in a medical faculty in Ankara. TSK Koruyucu Hekimlik Bülteni., 4 (4), 151-171 (21 pages).

\section{AUTHOR (S) BIOSKETCHES}

Müderrisoðlu, H., Ph.D. lecturer in Faculty of Forestry, Departmant of Landscape Architecture, Duzce University, 81100 Beciyorukler Koyu, Düzce, Turkey. E-mail: haldunm@duzce.edu.tr

Altanlar, A., MSc. research assistant in Faculty of Architecture, University of Amasya, Turkey. E-mail: aslial78@hotmail.com 